\title{
Contribution of the Satellite Observation on the Analysis and the Forecast of the State of Air Pollution in TOGO
}

\author{
Mignanou Yawovi Amouzouvi ${ }^{1}$, Koffi Sagna ${ }^{1,}$, , Milohum Mikesokpo Dzagli ${ }^{1}$, \\ Sidéra Kodjovi Edjame ${ }^{2}$, Agbéko Messanh Mohou ${ }^{1}$ \\ ${ }^{1}$ Department of Physics, University of Lomé, Lomé, Togo \\ ${ }^{2}$ Department of Geography, University of Lomé, Lomé, Togo
}

Email address:

ksagna@univ-lome.tg (K. Sagna)

${ }^{*}$ Corresponding author

To cite this article:

Mignanou Yawovi Amouzouvi, Koffi Sagna, Milohum Mikesokpo Dzagli, Sidéra Kodjovi Edjame, Agbéko Messanh Mohou. Contribution of the Satellite Observation on the Analysis and the Forecast of the State of Air Pollution in TOGO. American Journal of Environmental Protection. Vol. 8, No. 1, 2019, pp. 31-38. doi: 10.11648/j.ajep.20190801.15

Received: February 14, 2019; Accepted: March 18, 2019; Published: April 3, 2019

\begin{abstract}
Nowadays, there is a crucial question about the quality of the air that people breathes in Togo and many problems that its pollution would cause on the human health (respiratory, pulmonary and cardiovascular diseases, increase of infections) and on the environment (destruction of the ozone layer, global warming, climatic catastrophes). The lack of precise information on the different sources of pollution, the state and degree of pollution of Togolese cities, by the government or municipal authorities and policymakers, which would enable them to take commitments to limit air pollution in the country, made that the phenomenon of pollution persists. The present study aims to characterize the atmospheric pollution situations of the cities of Togo through the determination of the degree of pollution in Togo using the satellite measurements. The state of pollution of the atmosphere in Togo was performed by simulations using GIOVANNI software and satellite data from NASA. This research provides additional information on the variability of the pollutants according to time and will help government to foresee the eventual consequences. The results obtained allowed drawing up maps of the state of pollution of Togolese cities, knowing its sources and the average quantities of polluting particles released in Togo every year. The variation of the rate of these pollutants in the atmosphere in Togo also forecasts the degree of pollution of its cities and the estimate gave $481 \mathrm{ppm}$ for $\mathrm{CO}_{2}, 142.10^{-5}$ particles. ${ }^{-2}$ of $\mathrm{CO}, 436.81021 \mathrm{~mol}_{\mathrm{cm}} \mathrm{cm}^{-2}$ of $\mathrm{CH}_{4}$ particles, $56.210^{-7} \mathrm{Kg} . \mathrm{m}^{-2}$ of $\mathrm{SO}_{2}$ in the atmosphere in Togo in 2050. The results showed that the capital Lomé is more polluted.
\end{abstract}

Keywords: Atmospheric Pollution, Satellite Data, Polluting Particles, Togo

\section{Introduction}

Many human activities today, such as the use of fossil fuels, the operation of the oil, mining and gas industries, etc., contribute to the pollution of the atmosphere [1]. Other atmospheric pollutants result from wood combustion, waste and landfills incineration, livestock waste, the use of fertilizers and chemicals, and pollution from exhaust fumes released in the past atmosphere by gasoline and diesel engines, etc. [1].

In Togo, atmospheric pollution is accentuated over the years because of population growth on the one hand and economic activities on the other hand observed around big cities such as Lomé, Kara, Vogan, Tabligbo, Dapaong, Mango, etc.

Pollution in the big cities of Togo is due to the emission in the atmosphere of the engines' exhaust gases of vehicles [1], proliferation of motorcycles commonly known as Zemidjan (Taxi motos used to carry passengers), gaseous pollutants released by extractive mining and manufacturing industries such as the SNPT (New Society of Phosphate of Togo), CIMTOGO (Cement of Togo), free zone industries, etc. including domestic pollution related to the incineration of house and agricultural waste and bush fires.

This atmospheric pollution resulted from the emission into the atmosphere of polluting gases such as carbon dioxide $\left(\mathrm{CO}_{2}\right)$, carbon monoxide $(\mathrm{CO})$, nitrogen oxides $\mathrm{NO}_{\mathrm{X}}$, volatile 
compounds and aerosols, etc. [2].

The effect of this pollution on the health of Togolese and their environment is not to be overlooked because these pollutants cause respiratory problems, chronic coughs, allergies, skin discomfort, genetic problems frequently encountered in our hospitals and clinics. In the environment context, most of these gases are greenhouse gases [3, 4].

In Togo, the effects of this pollution, such as climatic catastrophes, global warming, and scarcity of rain, would lead to drought, floods, a short rainy season, a short harmattan time or nonexistent $[5,6]$.

The study of this pollution will perform the identification of the various pollutants released into the atmosphere in Togo and the distribution of pollution sources over the area and an estimate of the rate of each pollutant in the future.

This work aims to identify and to evaluate the concentration of atmospheric pollutants and to estimate the distribution of the sources of air pollutant emissions over the whole territory and to predict the rate of these emissions using simulations of data from satellite sensing methods.

This allowed to determine the different characteristics of the pollution rate of each pollutant, the variation of the pollution rate of the different cities of Togo, the sources of pollution in a general way, those caused by the cement plants, the refineries, the mining and extractive industries, road traffic in a particular way in Togo.

The results will show the alarming degree of pollution status and can be used by the government in order to predict an estimate of its rate in the atmosphere in Togo.

\section{Methodology}

Many methods currently allow the detection of atmospheric pollutants. Non-spectroscopic passive methods that are pollutant detection techniques based on physical and chemical processes such as chromatography mass spectrometric and Absorption analysis, Colorimetry, Titrimetry fluorometry, conductimetry, amperometry and other optical methods based on the laser diode spectroscopy such as: Optical Differential Absorption Spectroscopy (DOAS), Laser Imaging Detection And Ranging (LIDAR) / Absorption or Differential LIDAR (DIAL), Tunable Laser Diode Absorption Spectroscopy (SDLA), Laser-Induced Fluorescence (FIL) [7, 8] . All these techniques mentioned above do not make it possible to describe the transport of pollutants at a long distance. Therefore, there is a need for existing complementary networks providing information on areas not covered by in situ measurements. Thus, the satellite method for the detection of atmospheric pollutants makes an enormous contribution to the detection of atmospheric pollutants [9].

For information on pollutants, the satellite measurements are used to characterize the sources and degrees of pollution in the Togolese atmosphere. These satellites' data allowed to describe the transport of pollutant plumes throughout the territory of Togo, the variation of the pollutant levels in the atmosphere and the regions that cause atmospheric pollution in Togo in order to control the existing state of pollution of the atmospheric pollutants [10].

Many of the pollutants detected are currently measured by one satellite sensor. These satellites of NASA through their database give information to study the pollution of the different cities of Togo, the state of pollution in $\mathrm{PM}_{2.5}$ and $\mathrm{PM}_{10}$, the $\mathrm{CO}_{2}, \mathrm{O}_{3}, \mathrm{VOC}$, the aerosols, $\mathrm{SO}_{2}$, the $\mathrm{NO}_{\mathrm{X}}$ in the atmosphere knowing their variation versus the time regardless of the installation of a network of ground measurements [10].

Description of the method of detection of $\mathrm{CO}$ and $\mathrm{NO}_{2}$ by satellite channel used

NASA's satellite mission for example is based on a technique called gas filter radiometry. The MAPS instrument determines the mixing ratio of $\mathrm{CO}$ in the atmosphere by comparing the measured thermal energy of the atmosphere with the thermal energy of a known amount of CO carried on board the instrument. Thermal energy is emitted by the surface of the Earth and goes back into the atmosphere. When the thermal energy passes through the atmosphere, it is absorbed by atmospheric carbon monoxide and retransmitted at a frequency corresponding to that of CO. The MAPS instrument is designed to be sensitive to thermal energy at this unique frequency of $\mathrm{CO}$. This unique frequency can be considered as a footprint of atmospheric CO [11].

The thermal energy of the atmosphere entering the MAPS instrument is divided into three beams. A beam passes through a gas cell containing $\mathrm{CO}$ and falls on an electronic detector that measures the amount of thermal energy contained in the filtered beam. The second beam falls directly on a second electronic detector without passing through a gas filter. The voltage difference between the first and second detectors is used to determine the amount of $\mathrm{CO}$ present in the atmosphere.

The third thermal energy beam passes through a gas cell containing nitrous oxide and then falls on a third detector. This third beam is used to determine the amount of nitrous oxide in the lower atmosphere [12].

This technique of CO pollutant detection by the MAPS mission is the same to determine the rate or degree of pollution of other atmospheric pollutants such as $\mathrm{SO}_{2}, \mathrm{CO}_{2}$, $\mathrm{CH}_{4}, \mathrm{O}_{3}$ by NASA specific satellites [13].

Finally, from the GIOVANNI software, the digital data are simulated to obtain the results.

\section{Result at Set Discussion}

The figures (figure 1) obtained from the different simulations show the different satellite images of NASA. In this case of detection of atmospheric pollutants: these maps in figure 1 show the different sources of pollution and the levels of atmospheric pollution in the various cities of Togo. 


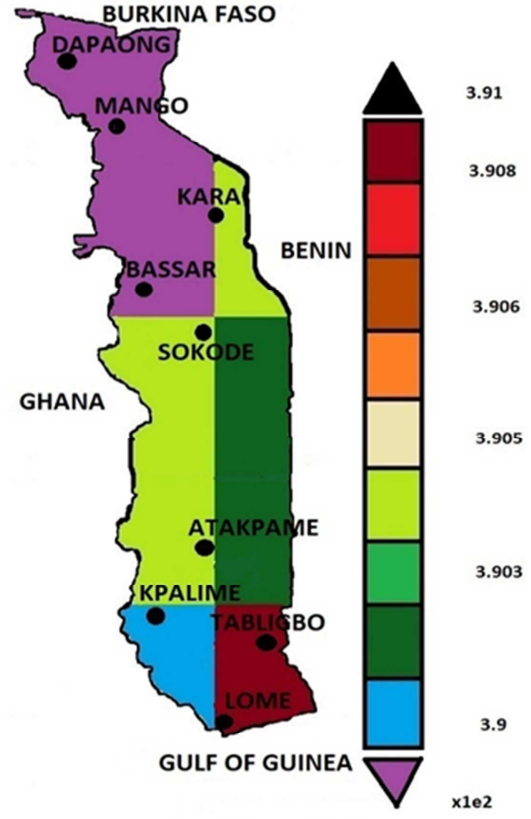

A

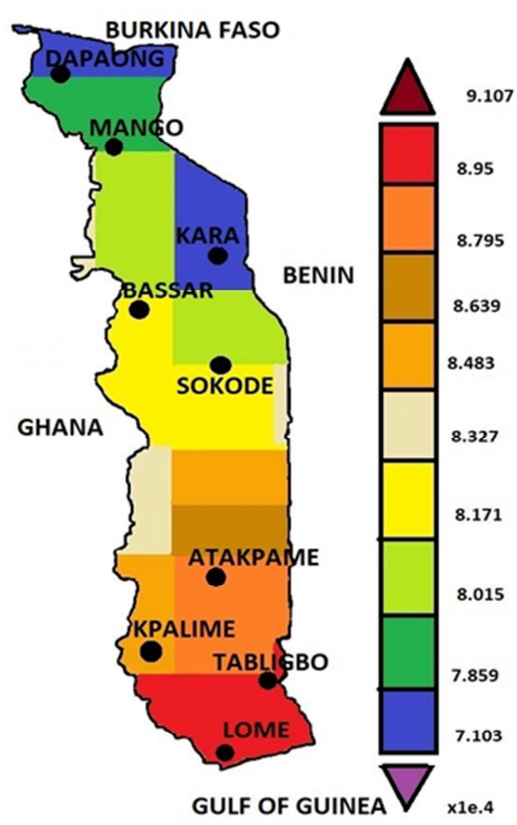

$\mathrm{B}$

Figure 1. Cartography of Togo showing the sources of Pollution over the territory between January 2005 and January 2018: A-CO and B-CO 2 .

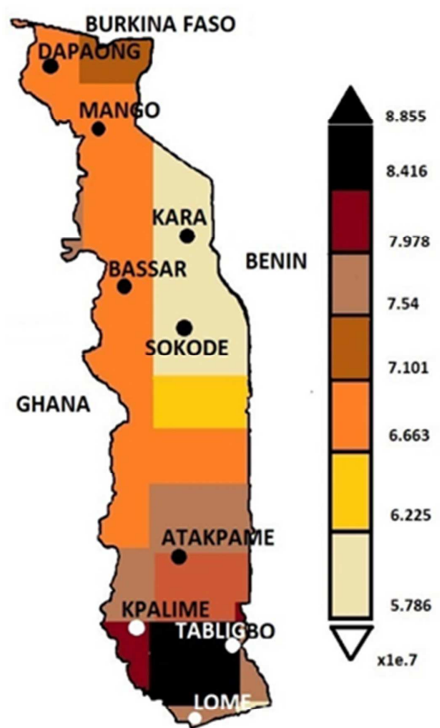

GULF OF GUINEA

A

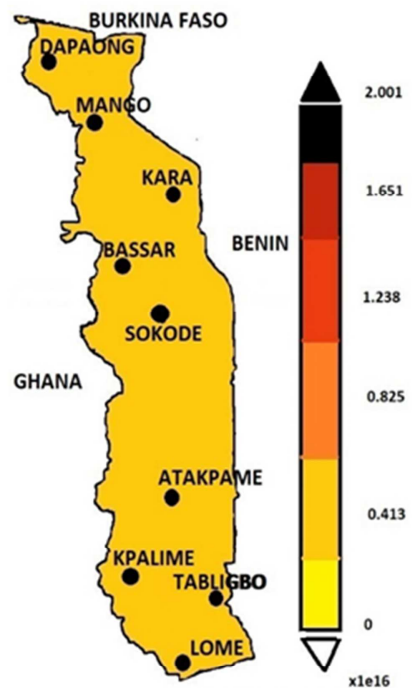

GULF OF GUINEA

$\mathrm{B}$

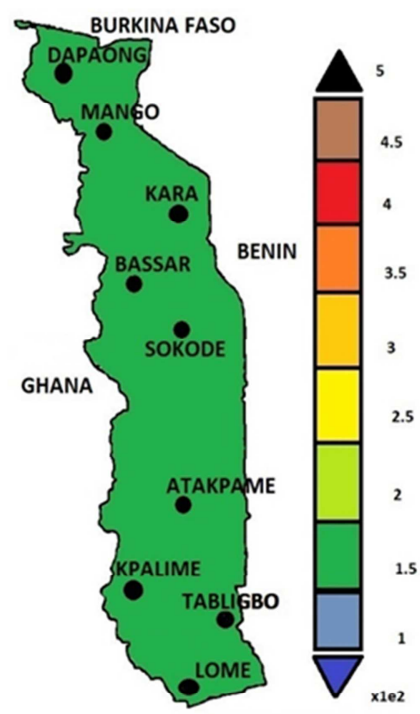

GULF OF GUINEA

$\mathrm{C}$

Figure 2. Cartography of Togo showing the sources of Pollution on the extent of the territory between January 2005 and January 2018: $\mathrm{A}-\mathrm{SO}_{2} \mathrm{~B}-\mathrm{O}_{3}$ and $\mathrm{C}$ $\mathrm{NO}_{2}$.

Figures 1-A, 1-B, 2-A, 2-B and 2-C show different examples of transport of atmospheric pollutants observed in Togo between January 2005 and January 2018, these simulations from GIOVANNI software help to have data to show the uneven distribution of pollution in Togo. Thus, the sources of pollutants release in the atmosphere in Togo by industries and vehicles (cars and motorcycles) are not the same. It can be seen from these different figures (maps of Togo) that this pollution is not legally distributed.

Moreover, the pollution rate is not the same for the different atmospheric gaseous pollutants, it differs from one region to another.

a In the case of carbon dioxide $\left(\mathrm{CO}_{2}\right)$ and carbon monoxide (CO), the emissions of these pollutants would be unevenly distributed over the entire territory of Togo. They are more accentuated in the maritime region (in the south of Togo) on the cartography where a high rate of pollutants was found. This could be due to the presence of the manufacturing industries like NIOTO (New Oleaginous Industry of Togo), the harbor of Lomé, the industries of the Free Zone, CIMTOGO (Cement of Togo) in Lomé. In the prefecture of Vo and 
Yoto, mining and extractive industries like SNPT (New Company of Togo Phosphates), cement plants like WACEM (Western African Cement) cement manufacturing industry called SCAN - Togo from Sikakondji are the main sources. This pollution is also caused by the high concentration of the population in these areas due to the rural exodus that pollute the atmosphere with the use of gasoline engines and Diesel resulting from the proliferation of motorcycles and cars including that caused by bush fires, the incineration of agricultural and domestic wastes [14].

b In the case of $\mathrm{NO}_{2}$ the pollution is the same throughout the territory. From Lomé to Dapaong, the pollution is uniform, which is explained by the emission due in most cases from bush fires in the agricultural world and the incineration of domestic pollutants. It can be explained also by the emission of the oxides nitrogen released from the exhaust gases of gasoline and diesel engines used throughout the territory. This observation is the same for the ozone level because ozone comes from the reaction between nitrogen dioxide and atmospheric oxygen, this rate also remains constant over the entire territory [15].

In the case of Togo, GIOVANNI's basic data from NASA satellites are used to simulate the change in the rate of gaseous pollutants in the atmosphere in Togo. These different simulations made it possible to obtain the following curves on the state of pollution in Togo:

c In the case of carbon monoxide, the simulation allowed to represent the change in the level of $\mathrm{CO}$ in the atmosphere in Togo versus the time.

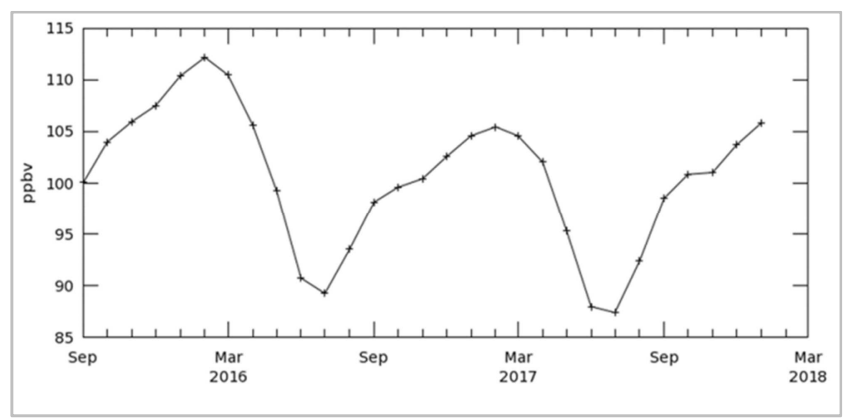

Figure 3. Variation of CO rate in the atmosphere in Togo between 20162018.

Figure 3 shows the variation of the average carbon monoxide rate over the territory of Togo between September 2016 and March 2018. The variation of the concentration is expressed in ppbv (parts per billion by volume), characterized by the maximum pollution between $\mathrm{CO}$ expressed about 110 ppbv. This concentration peaks every year in January, February and March, and it decreases between June and August of each year.

The high rate of this pollution between January and March could be explained by a significant $\mathrm{CO}$ emission supported by an increase in temperature during these periods. There is $\mathrm{CO}$ emission, which is could be due to bush fires and the combined action of heat and drought [16].

The low rate between June and August is caused by favorable weather conditions such as the big rainy season which limits the $\mathrm{CO}$ pollution rate in Togo. This phenomenon is shown by the Figure 4 .

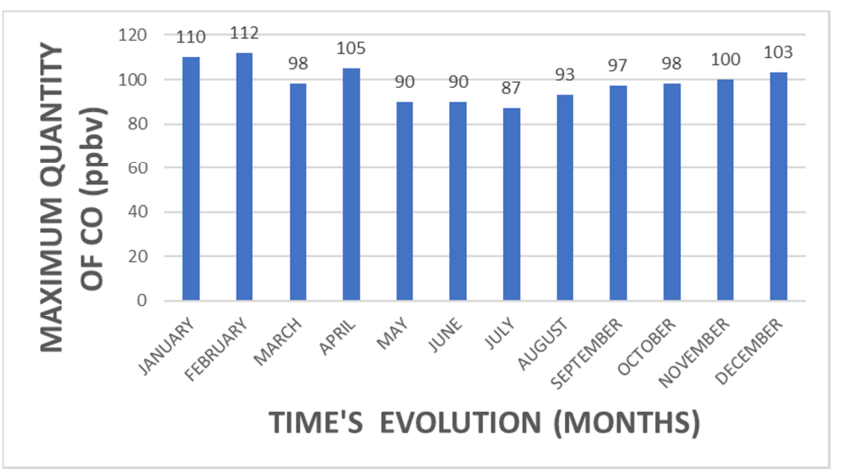

Figure 4. Representation of the carbon monoxide (CO) pollution in Togo diagram of the year 2015.

The different simulations in the case of carbon monoxide also made, represent the mass of carbon monoxide emitted per unit of surface in the atmosphere in Togo which is shown by the figure 5 .

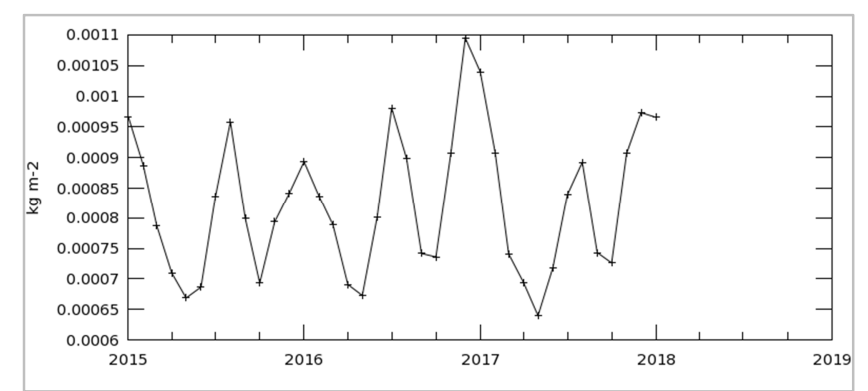

Figure 5. Variation of the CO in the atmosphere in Togo between 2015 2018.

In the figure 5 there is a variation of pollutants $(\mathrm{CO})$ per unit area during the same year and versus the time in Togo, which shows that $\mathrm{CO}$ is emitted into the atmosphere, a phenomenon that would be in incomplete combustion principles [16]. The magnitude of this phenomenon versus the time is shown in Figure 6.

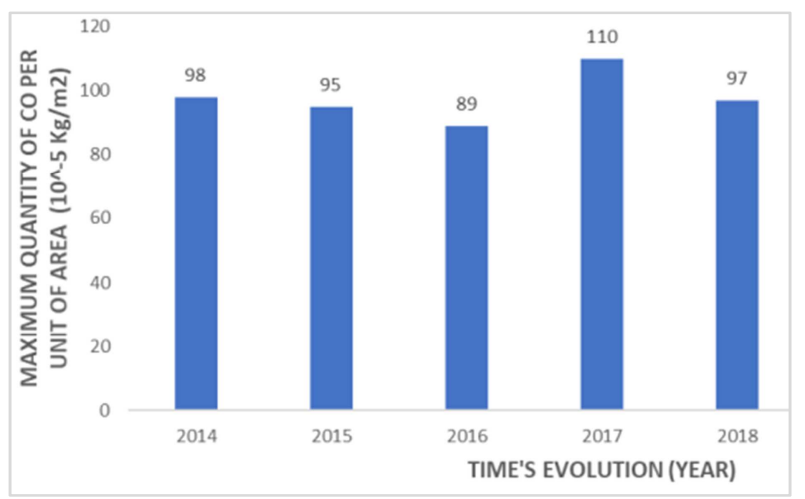

Figure 6. Representation of the carbon monoxide (CO) pollution in Togo diagram from 2016 to 2017. 
Figure 6 showed a variation of the pollutant rate estimated in the atmosphere in Togo per unit area versus the time. This rate varies each year and the maximum pollution rate is observed in 2017 , following this variation the pollution rate is increasing.

These different simulations help to estimate $\mathrm{CO}$ pollution versus the time which is represented by the figure 7 .

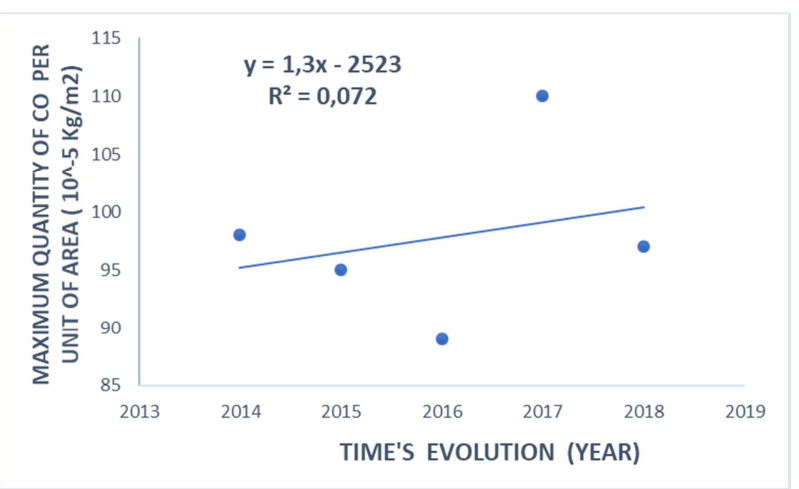

Figure 7. Progression of CO pollution versus the time.

The Figure 7 shows an estimate of the pollution rate in the atmosphere, the regression law is given by equation (1):

$$
y=1.3 x-2523
$$

Based on this result, if a decision is not made, $\mathrm{CO}$ pollution in 2050 would be estimated to $142.10^{-5} \mathrm{CO}$ particles. $\mathrm{m}^{-2}$.

d In the case of carbon dioxide, the simulations allowed having the figure 8 that shows the variation of the number of $\mathrm{CO}_{2}$ particles expressed in ppm (part per million).

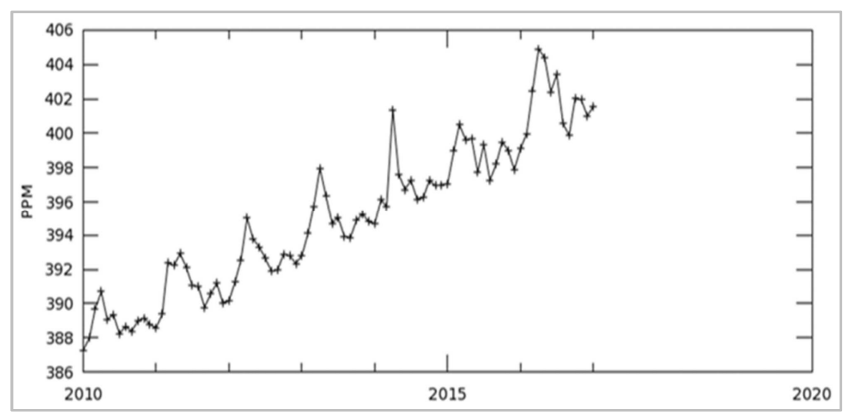

Figure 8. Variation of the $\mathrm{CO}_{2}$ rate in the atmosphere in Togo between 20162018.

Figure 8 shows a variation of the average carbon dioxide content over the territory of Togo between September 2010 and March 2020.

There is uncontrolled pollution in the atmosphere in Togo. The rate of particles in the atmosphere expressed in ppm is increasing, it evolves in time.

This is due to the production of carbon dioxide released by the extractive, manufacturing and mining industries. Its production is also due to population growth especially in large cities that pollute the atmosphere by emission of exhaust gases from their gasoline and diesel engines [15].
This variation in time is represented by figure 9 .

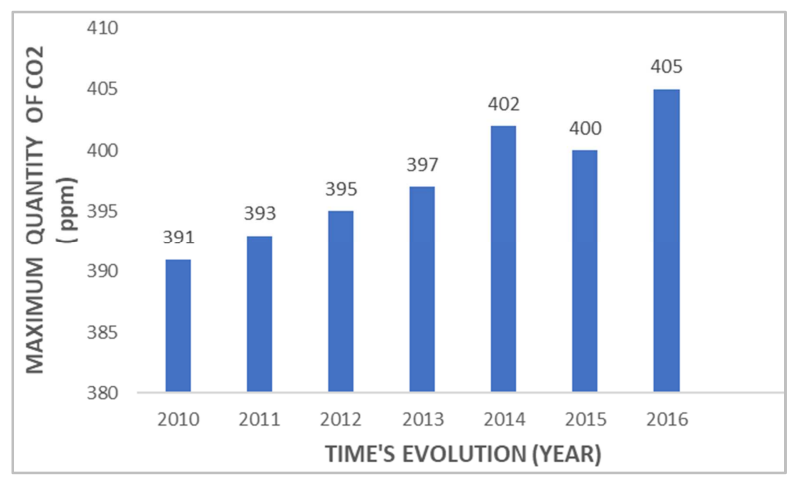

Figure 9. Representation of the carbon dioxide $\left(\mathrm{CO}_{2}\right)$ pollution diagram for the year 2016 to 2017.

The different simulations help to estimate $\mathrm{CO}_{2}$ pollution versus the time. Figure 10 shows the pollution by the $\mathrm{CO}_{2}$ versus the time.

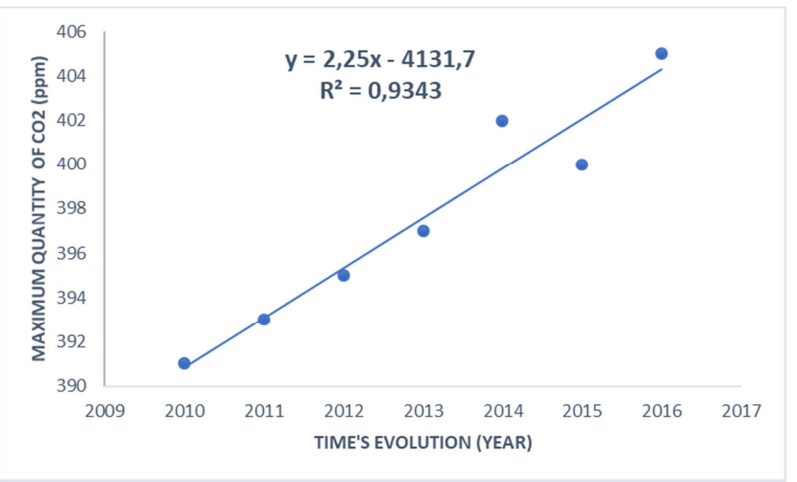

Figure 10. Progression of pollution in $\mathrm{CO}_{2}$ in Togo versus the time.

This estimate is shown by the figure 10 that allows to have a linear regression law given by equation (2):

$$
y=2.25 x-4131.7
$$

This figure allows to estimate the $\mathrm{CO}_{2}$ level in the atmosphere in 2050 at $481 \mathrm{ppm}$ in Togo.

e The different simulations were performed for $\mathrm{CH}_{4}$ in the atmosphere in Togo. A variation in the methane level has been observed versus the time, it varies almost uniformly in time. This variation of the pollution rate is expressed in mol.cm ${ }^{-2}$.

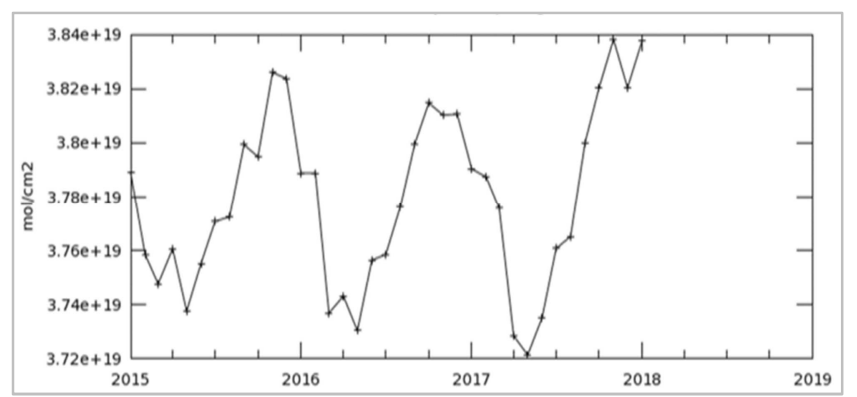

Figure 11. Change in the rate of $\mathrm{CH}_{4}$ in the atmosphere in Togo between 2016-2018. 
Figure 11 shows that $\mathrm{CH}_{4}$ pollution varies rapidly in recent years and peaks in 2018. This phenomenon is due to different activities such as pollutants released by engines, different mining and extractive industries etc. The magnitude of this phenomenon is represented versus the time by the following figure 12:

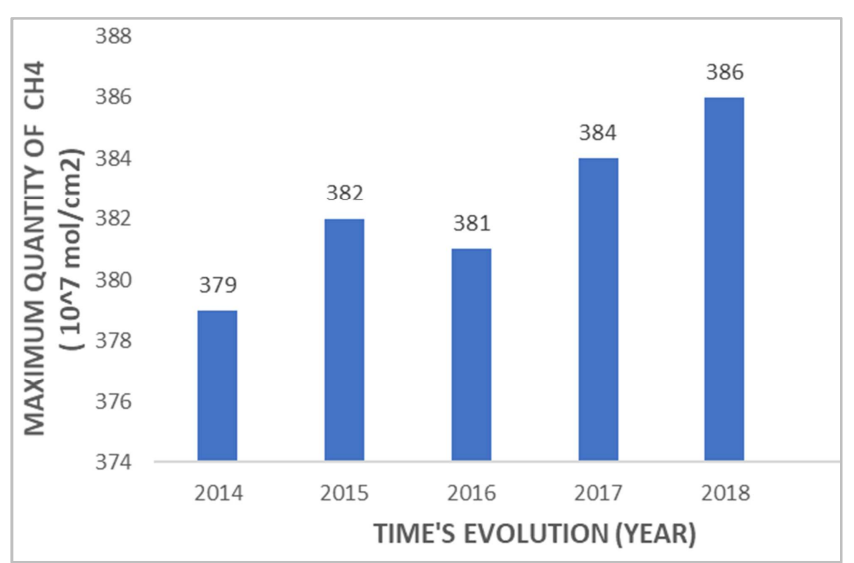

Figure 12. Representation of the carbon monoxide $\left(\mathrm{CH}_{4}\right)$ pollution diagram from 2015 to 2018.

This variation makes it possible to determine a regression law given by the equation (3):

$$
y=1.6 x-2843.2
$$

The figure 13 allows to estimate the pollution in $\mathrm{CH}_{4}$ if the conditions remain the same.

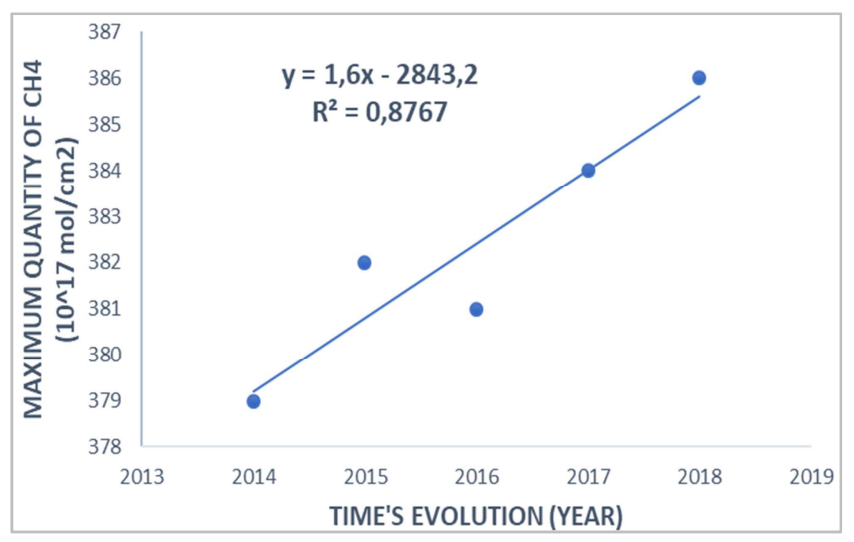

Figure 13. Progression of $\mathrm{CH}_{4}$ pollution versus the time.

The rate of this pollutant according to the graph is not stable. There is a variation of pollution over the years and the pollution increases. It would also be due to human activities such as the exhaust gases of engines, pollutants released by industries, bush fires that are in perpetual growth [17]. Methane pollution would be estimated through the regression law by $436.810^{21} \mathrm{~mol} . \mathrm{cm}^{-2}$ particles of methane pollutants in 2050.

$\mathrm{f}$ In the case of sulfur dioxide, a change in the pollutant $\mathrm{SO}_{2}$ rate versus the time has been observed also, this phenomenon is represented by figure 14 .

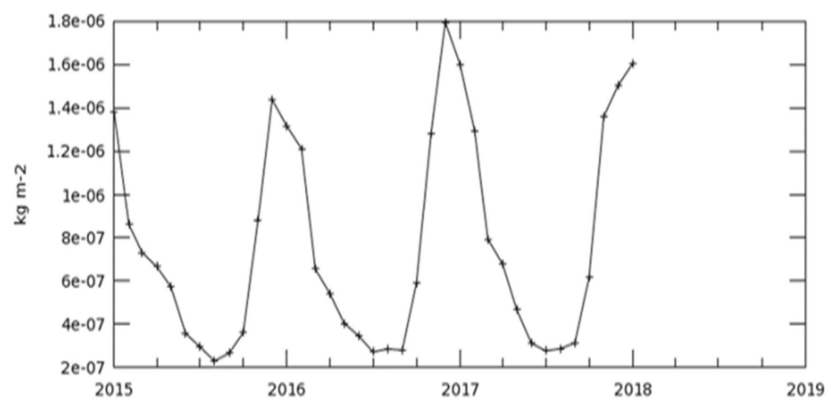

Figure 14. Variation of the $\mathrm{SO}_{2}$ rate in the atmosphere in Togo between 2015-2018.

On this graph (figure 14), the increase of the mass ratio per unit area of sulfur dioxide in Togo between 2015 and 2018 is shown. The variation of the mass rate each year and during the same year is noted. It noticed that in the first three quarters of each year this rate is high but become low in the middle of the year. This decrease is explained by the great season of May to August which limits the rate of production of pollutants in the atmosphere.

In addition, pollution varies from one year to another. The increase of pollution rate in time is explained by the increasing use of gasoline and diesel engines that emit sulfur dioxide into the atmosphere, by bush fires and domestic pollutants.

This pollutant rate is increasing, changing versus time and going through its maximum in 2017. The phenomenon is accentuated every year by the use of engines of sulfur fuels which emit in the atmosphere a significant rate of sulfur dioxide without forgetting the large quantity released by the different mining, extractive and manufacturing industries [15, 17]. This variation is shown by the figure 15 .

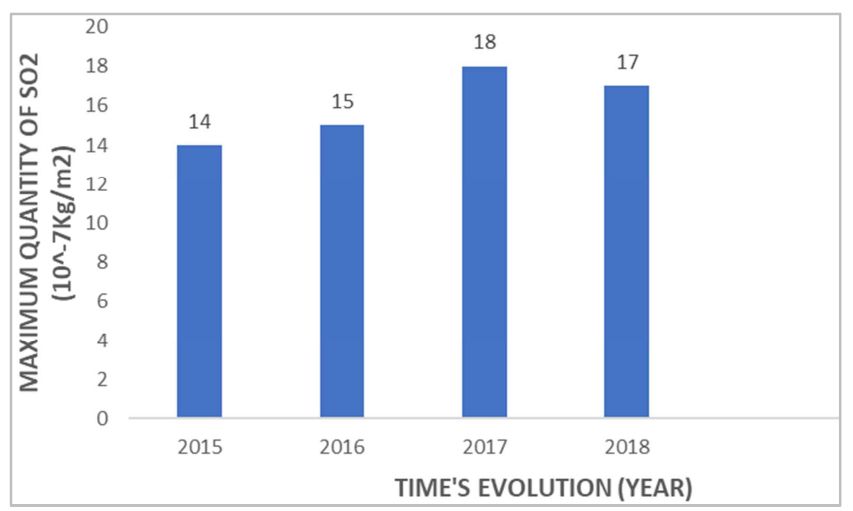

Figure 15. Representation of the carbon monoxide pollution diagram $\left(\mathrm{SO}_{2}\right)$ from 2015 to 2018 .

With this representation, the regression law for estimating the pollution rate of sulfur dioxide versus time is given by equation (4):

$$
y=1.2 x-2403.8
$$

The figure 16 allows to estimate the sulfur dioxide pollution in Togo, to $56.210^{-7} \mathrm{~kg} \cdot \mathrm{m}^{-2}$ in the year 2050 . 


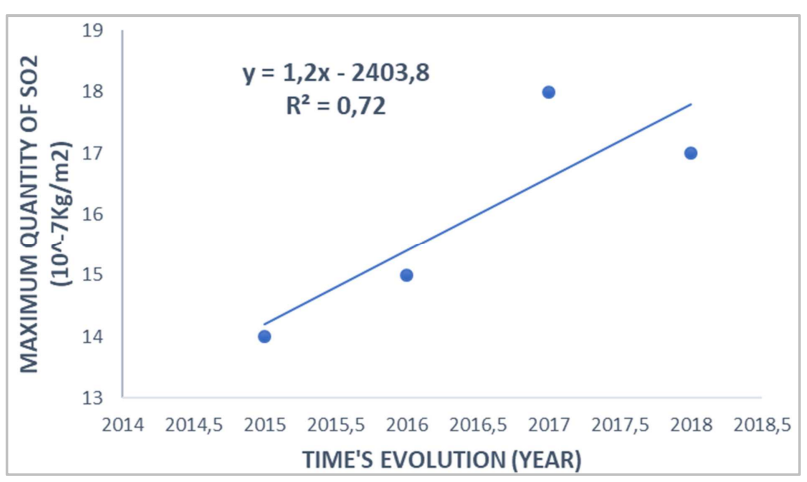

Figure 16. Progression of $\mathrm{SO}_{2}$ pollution versus the time.

\section{Conclusion}

The basic data of the different atmospheric pollutants in the atmosphere in Togo from the specific satellites was used with GIOVANNI software to monitor the environment because of the problems of instruments or the lack of sensing devices. Results contributed to know the degree of pollution of the various cities in Togo. The different simulations have shown that some regions in Togo are more polluted and this pollution is unevenly distributed, for instance Lomé remains the most polluted city because of the proliferation of different industries compared to other regions of Togo. Its population is the highest and this causes an excessive use of vehicles (cars and motorcycles) that emit in the atmosphere pollutants, especially $\mathrm{CO}, \mathrm{CO}_{2}$, harmful to the health and the environment.

These different simulations data performed the variation of atmospheric pollutants versus the time and the results showed that the pollutant rate is not the same for a given year. It varies in the same year and differs according to the conditions of the period. The increasing rate of atmospheric pollutants emitted every year showed an uncontrolled pollution from one year to other. Therefore, there is a need to review the techniques and system of depollution. The pollution rate of different pollutant gases in the atmosphere in Togo was estimated for $\mathrm{CO}_{2}, \mathrm{CO}$, $\mathrm{SO}_{2}, \mathrm{CH}_{4}$. Thus, the predicted estimate of gaseous pollutants would be in 2050 at $142.10^{-5}$ particles. $\mathrm{m}^{-2}$ of CO, $481 \mathrm{ppm}$ for $\mathrm{CO}_{2}, 436.810^{21}$ mol.cm ${ }^{-2} \mathrm{CH}_{4}$ particles, $56.210^{-7} \mathrm{~kg} . \mathrm{m}^{-2}$ of $\mathrm{SO}_{2}$ in the atmosphere in Togo.

\section{Acknowledgements}

Authors would like to thank the NASA for making its data available. The authors acknowledge financial support from SNPT (New Company of Togo Phosphates) and TOTAL_Togo.

\section{References}

[1] Koffi Sagna, Komi Apélété Amou, Tchamye Tcha-Esso Boroze, Djima Kassegne, Amah d'Almeida, Kossi Napo. Environmental Pollution due to the Operation of Gasoline Engines: Exhaust Gas Law. International Journal of Oil, Gas and Coal Engineering. Special Issue: Computer-Aided Reservoir Characterization Methods. Vol. 5, No. 4, 2017, pp. 39-43. doi: 10.11648/j.ogce.20170504.11.
[2] FLEMMING, Johannes, BENEDETTI, Angela, INNESS, Antje, et al. The CAMS interim reanalysis of carbon monoxide, ozone and aerosol for 2003-2015. Atmospheric Chemistry and Physics, 2017, vol. 17, no 3, p. 1945-1983.

[3] K. Sagna, A. Almeida, Supercritical evaporation of a drop paper published in international Journal of Research in Engeneering and Science (IJRES), ISSN (online): 2320-9364, (Print): 2320-9356, www.ijres.org Volume 2 Issue7//July 2014//pp .41.47.

[4] A. Ung, (2003). Cartographie de la pollution atmosphérique en milieu urbain à l'aide de données multisources (Doctoral dissertation, École Nationale Supérieure des Mines de Paris).

[5] E. Hache. (2014). Apport de la bande de Chappuis pour la mesure de l'ozone depuis un satellite géostationnaire pour la surveillance de la qualité de l'air (Doctoral dissertation, Université de Toulouse, Université Toulouse III-Paul Sabatier).

[6] L. Basly. (2000). Télédétection pour la qualité de l'air en milieu urbain (Doctoral dissertation, Université Nice Sophia Antipolis).

[7] SELlitTO, Pasquale, DI SARRA, Alcide, CORRADINI, Stefano, et al. Synergistic use of Lagrangian dispersion and radiative transfer modelling with satellite and surface remote sensing measurements for the investigation of volcanic plumes: the Mount Etna eruption of 25-27 October 2013. Atmospheric Chemistry and Physics, 2016.

[8] BURSIK, Marcus, JONES, Matthew, CARN, Simon, et al. Estimation and propagation of volcanic source parameter uncertainty in an ash transport and dispersal model: application to the Eyjafjallajokull plume of 14-16 April 2010. Bulletin of volcanology, 2012, vol. 74, no 10, p. 2321-2338.

[9] C. Clervaux, A. Boynard, L. Clarisse, M. George, J. HadjiLazaro, H. Herbin, D. Hurtmans, M. Pommier, A. Razavi, S. Turquety, C. Wespes, and P.-F. Coheur, Monitoring of atmospheric composition using the thermal infrared IASI/MetOp sounder, Atmos. Chem. Phys., 9, 6041-6054, 2009.

[10] A. Coman, G. Foret, M. Beekmann, M. Eremenko, G. Dufour, B. Gaubert, A. Ung, C. Schmechtig, J.-M. Flaud, and G. Bergametti: Assimilation of IASI partial tropospheric columns with an Ensemble Kalman Filter over Europe, Atmos. Chem. Phys., 12, 2513- 2532, doi:10.5194/acp-122513-2012, 2012.

[11] J. Cuesta,, M. Eremenko, X. Liu, G. Dufour, Z. Cai, M. Höpfner, T. von Clarmann, P. Sellitto, G. Foret, B. Gaubert, M. Beekmann, J. Orphal, K. Chance, R. Spurr and J.-M. Flaud (2013), Satellite observation of lowermost tropospheric ozone by multispectral synergism of IASI thermal infrared and GOME-2 ultraviolet measurements over Europe. Atmos. Chem. Phys., 13 (19), 9675-9693.

[12] M. N. Deeter, D. P. Edwards, J. C. Gille, and H. M. Worden (2015), Information content of MOPITT CO profile retrievals: Temporal and geographical variability, J. Geophys. Res. Atmos., 120 (24), 12723-12738, doi:10.1002/2015JD024024.

[13] C Doche, G. Dufour, G. Foret, M Eremenko, J. Cuesta, Beekmann, M. P. and Kalabokas: Summertime troposphericozone variability over the Mediterranean basin observed with IASI, Atmos. Chem. Phys., 14, 10589-10600, doi: 10.5194/acp-14-10589-2014, 2014. 
[14] R. Engelen, J. Flemming, J., P. Hedelt, A. Inness, Suttie, M. and Valks, P. (2015) Assimilating Volcanic SO2 Satellite Data in the Copernicus Atmosphere Monitoring Service Global Data Assimilation System. In: ATMOS 2015 Abstract Book. ESA ATMOS 2015, 8. 12. Jun. 2015, Kreta, Griechenland.

[15] J. Flemming, A. Benedetti, A. Inness, R. J. Engelen, L. Jones, V. Huijnen,... \& V. H. Peuch, (2017). The CAMS interim reanalysis of carbon monoxide, ozone and aerosol for 20032015. Atmospheric Chemistry and Physics, 17 (3), 1945-1983.
[16] A. Fortems-Cheiney, G. Dufour, L. Hamaoui-Laguel, G. Foret, G. Siour, M. Van Damme, F. Meleux, P.-F. Coheur, C. Clerbaux, L. Clarisse, O. Favez, M. Wallasch, and M. Beekmann, Unaccounted variability in $\mathrm{NH}_{3}$ agricultural sources detected by IASI contributing to European spring haze episode, Geophys. Res. Lett., 43, doi:10.1002/2016GL069361, 2016.

[17] R. Zhang,, Wang, G., Guo, S., Zamora, M. L., Ying, Q., Lin, Y.,... \& Wang, Y. (2015). Formation of urban fine particulate matter. Chemical Reviews, 115 (10), 3803-3855. 